\title{
POLA KOMUNIKASI PENGASUH DAN ANAK ASUH DALAM \\ PENGEMBANGAN BAKAT MINAT DI SOS CHILDREN'S \\ VILLAGE DESA TARUNA MEULABOH KABUPATEN ACEH BARAT
}

\author{
Siti Hajar' ${ }^{1}$, Reni Kumala Sari² \\ STAIN Teungku Dirundeng Meulaboh \\ E-mail: sitiihajar9@gmail.com ${ }^{1}$; reni.sekedang@gmail.com ${ }^{2}$
}

\begin{abstract}
Abstrak
Lingkungan tempat manusia tumbuh kembang tidak terlepas dari proses komunikasi. Setiap orang punya cara yang berbeda dalam menyampaikan pesan agar pesan yang dimaksud dapat dipahami. Para pengasuh sebagai pengganti orang tua di Panti Asuhan memiliki tanggung jawab besar dalam mendidik anak asuh. Tentunya memiliki pola komunikasi yang baik demi mengembangkan bakat dan minat mereka agar menjadi lebih baik dari sebelumnya. Dalam penelitian ini meneliti Panti Asuhan SOS Children's Village di Desa Taruna Meulaboh Kabupaten Aceh Barat. Penelitian ini bertujuan untuk mengetahui pola komunikasi antara pengasuh dan anak asuh dalam pengembangan bakat minat di SOS Children's Village Desa Taruna Meulaboh Kabupaten Aceh Barat. Pendekatan yang digunakan dalam penelitian ini adalah pendekatan kualitatif deskriptif. Teknik yang digunakan dalam pengumpulan data dengan wawancara dan dokumentasi. Subjek dalam penelitian ini adalah ketua pimpinan SOS children's village Desa taruna Meulaboh Kabupaten Aceh Barat dan 2 orang pengasuh dari kamar yang berbeda, sedangkan objek penelitian adalah semua data dan informasi yang relevan dengan pola komunikasi antara pengasuh dan anak asuh di SOS children's village Desa Taruna. Hasil penelitian menunjukkan pola komunikasi yang digunakan Di SOS Children's Village Desa taruna Meulaboh dalam pengembangan bakat dan minat anak asuh yaitu menggunakan pola komunikasi Antar pribadi, komunikasi umum, dan komunikasi kelompok. Dari ketiga pola tersebut dapat memberi efek kepada anak dan dapat membuka wawasan anak-anak serta mempermudah anakanak dalam mengasah bakat dan minatnya.
\end{abstract}

Kata kunci: Pola Komunikasi, Bakat minat, SOS children's village Desa Taruna

\section{Abstract}

The environment which humans grow and develop is inseperable from the communication process. Everyone has a different way of conveying message that can be understood. Caregivers in lieu of parent at the Orphanage have a big responsibility in educating foster children. Certainly have a good communication pattern in order to develop their talents and interests to be better than before. This study examines SOS's Children Village of Taruna Meulaboh, Aceh Barat District. This study aims to determine the pattern of communication between caregivers and foster children in the development of talents in SOS Children's Village of Taruna 
Meulaboh, Aceh Barat District. The research is using qualitative approach. The method of data collecting is using Interview and documentation. The subject of this study were chairman of SOS Children's Village of Taruna Meulaboh and 2 (two) caregivers from different rooms, while the object of study was all data information relevant to communication pattern. The results show that communication pattern used by SOS Children's Village of Taruna Meulaboh is using interpersonal communication, public communication, and group communication. Three pattern deducted an effect on children insight and make it easier for children to hone their talent and interest.

Keyword: Communication Pattern, talent of interest, SOS Children's Village of Taruna Meulaboh.

\section{PENDAHULUAN}

Manusia merupakan makhluk sosial yang saling berhubungan dan berinteraksi dengan manusia lainnya. Dalam segala aktivitas manusia dengan manusia lain sangat tidak terlepas dari komunikasi yang merupakan satu alat vital dalam penyampaian pesan yang dimaksud. Komunikasi bisa dilakukan dimana saja selama ada komunikator dan komunikan nya, baik itu di sekolah, perusahaan, ketika jual beli di pasar dan lain-lain. Dalam berkomunikasi tentunya kita memperhatikan pola bentuk atau cara yang baik dalam menyampaikan pesan agar mencapai kesepahaman.

Komunikasi sangat penting peranannya bagi kehidupan sosial, karena komunikasi merupakan proses dinamika transaksional yang mempengaruhi perilaku, yang mana sumber dan penerimanya sengaja menyandi perilaku mereka untuk menghasilkan pesan yang mereka salurkan guna merangsang atau memperoleh sikap atau perilaku konsekuensi dari hubungan sosial. ${ }^{1}$ Pola komunikasi diartikan sebagai pola hubungan dua orang atau lebih dalam proses pengiriman dan penerimaan pesan dengan cara yang tepat, sehingga pesan yang dimaksud dapat dipahami. ${ }^{2}$

Komunikasi yang baik dalam keluarga sangat berpengaruh bagi anak dalam membentuk kepribadiannya.Sama halnya dengan lingkungan luar keluarga (bukan

\footnotetext{
${ }^{1}$ Deddy Mulyana, Ilmu Komunikasi Suatu Pengantar (Bandung: PT. Remaja Rosdakarya,2008), h. 94

${ }^{2}$ Syaiful BahriDjamarah, Pola Asuh Orang Tua dan Komunikasi dalam Keluarga (Jakarta: PT. Rineka Cipta,2017), h.1
} 
keluarga) seperti di SOS juga membutuhkan komunikasi yang baik antara pengasuh antara dan anak asuh.Komunikasi yang baik dapat menciptakan kenyamanan dan kedekatan bagi pengasuh dan anak asuh.Anak yang bertumbuh kembang di SOS tidak jauh berbeda dengan anak yang tinggal bersama orangtua kandung.Anak di SOS juga sangat membutuhkan perhatian dan kasih sayang dari pengasuhnya sebagai pengganti orangtua kandung mereka.Disinilah peran pengasuh sebagai pengganti orangtua dibutuhkanbagi anak-anak asuh untuk memberi asuhan terbaik bagi mereka dalam mengembangkan bakat minatnya. Secara otomatis pengasuh memiliki tanggung jawab sama halnya dengan orangtua kandung mereka dalam menetukan masa depan anak asuhnya. Hubungan pengasuh dengan anak asuh lah yang menentukan komunikasi anak tersebut dalam masa perkembangan dan pertumbuhannya.

Bagi anak asuh, pengasuh menjadi model yang ditiru dan diteladani. Jadi jika pengasuh menggunakan pola komunikasi yang baik diharapkan akan menciptakan pola asuh yang baik dan begitu sebaliknya. Kegiatan pengassuhan anak akan berhasil dengan baik jika pola komunikasi yang tercipta didasari dengan cinta dan kasih sayang dengan memposisikan anak sebagai subjek yang harus dibina, dibimbing, dididik dan bukan sebagai objek semata. ${ }^{3}$

Dalam penelitian ini penulis meneliti sebuah SOS children's village Desa Taruna di Meulaboh Kabupaten Aceh Barat.Penelitian ini bertujuan untuk mengetahui Pola komunikasi antara pengasuh dan anak asuh dalam pengembangan Bakat dan Minat di SOS Desa TarunaMeulaboh Kabupaten Aceh Barat.

\section{SOS CHILDREN'S VILLAGE DESA TARUNA}

\section{Sejarah SOS Children's Village Desa Taruna}

SOS children's village adalah organisasi nirlaba non-pemerintah yang aktif dalam mendukung hak-hak anak dan berkomitmen memberikan anak-anak yang telah beresiko kehilangan pengasuhan orangtua terhadap kebutuhan mereka, dapat dikatakan SOS adalah kampung anak atau keluarga dan rumah yang penuh kasih sayang. Di indonesia SOS pertama di bangun terletak di Jalan Teropong Bintang Lembang, bandung. Berkat bantuan Bapak Solihin G., Gubernur jawa barat pada 
waktu itu.SOS yang kedua berada di cibubur, Jakarta dan dilanjutkan dengan pembangunan SOS di beberapa tempat lainnya. Setelah kejadian tsunami tahun 2004 maka SOS dibangun di Aceh untuk menampung anka-anak yang kehilangan sanak keluarga akibat bencana tersebut, maka dibangunlah SOS children's village di Meulaboh yang diresmikan oleh Bupati Aceh Barat pada 25 Juni 2008, kemudian di Banda Aceh, Medan dengan masing-masing terdiri dari 15 rumah keluarga dengan fasilitas pendukungnya. Anak-anak yang berada dalam pengasuhan SOS children's village Indonesia dalam kisaran usia bayi hingga 21 tahun, dalma perkembangannya anak-anak asuh diberikan pendiidikan formal dan keterampilan. Untuk anak asuh yang berada dalam usia remaja, telah dibangun tempat tinggal yang khusus diperuntukkan bagi remaja semacam Wisma Remaja dandisediakan pula gedung dan sarana untuk keterampilan bagi remaja putra dan remaja putri. ${ }^{4}$

SOS children's village berfokus pada pengasuhan berbasis keluarga dan berjangka panjang, serta anak-anak yang tak dapat lagi tumbuh dengan keluarga biologisnya. SOS Children's Village dalam pengasuhan sos memiliki 2 model pengasuhan yaitu family base cara ( pengasuhan berbasis keluarga) dan family strengthening programme (penguatan keluarga). Di tahun 2017 skitar 4700 anak lebih yang ikut diasuh dalam program FSP yang tersebar di 9 SOS di Indonesia. Salah satu tujuannya yaitu memastikan anak-anak mendapatkan hak-haknya. Pada tahun 2017 juga tercatat 1171 anak yang diasuh dalam program FBC yag tersebar di 9 lokasi SOS di Indonesia. ${ }^{5}$

Bidang kerja di SOS yaitu memberikan hak-hak yang sama untuk pendidikan dan pelatihan bagi anak-anak seperti perawatan pra-sekolah, pendidikan pelatihan kejuruan sebagai pendukung keberhasilan anak di masa depan. SOS children'sVillage peduli pada setiap anak, khusuusnya mereka yang kehilangan pengasuhan dan anak-anak yang kekurangan hidup dalam kondisi sulit.Dasar tujuan dari pekerjaan di SOS adalah untuk menghormti, mempromosikan, dan membela hak-hak anak asuh.SOS juga memperluas bidang kerja melalui Program pemberdayaan Keluarga untuk keluarga yang kurang beruntung, untuk mencegah

\footnotetext{
${ }^{4}$ Tim Penyusun SOS, Profil SOS Desa Taruna Indonesia, Meulaboh: t.tp, t.th

${ }^{5}$ Ibid.
} 
terjadinya kondisi terburuk yang bisa menyebabkan anak-anak harus terpisah dari orangtuanya. ${ }^{6}$

Ciri khas suatu SOS Children's Village yang membedakan dengan lainnya adala pada sistem asuhan dna pendidikan yang diberikan kepada anak asuhnya. SOS Children's Village mengusahakan suatu pendekatan melalui suatu sistem terpadu menuju ke usaha-usaha Rehabilitasi, Resosialisasi, dan edukasi yang ditujukan kepada anak asuhannya dalam suasana keakrabab keluarga.Berdasarkan konsep SOS Children's Village, organisasi ini mempolopori suatu pendekatan keluarga dalam pengasuhan jangka panjang anak-anak yatim piatu dan terlantar. Konsep ini berdasarkan 4 prinsip : 1) Ibu: Setiap anak memiliki orangtua asuh, 2) Kakak adik: Ikatan keluarga tumbuh secara alamiah, 3) Rumah :Setiap rumah menciptakan suasana yang nyaman, 4) Desa : Keluarga SOS merupakan bagian dari masyarakat. $^{7}$

\section{Visi dan Misi SOS children's village}

Visi: 1) Setiap anak dibesarkan dalam keluarga, 2) Setiap anak tumbuh dala kasih sayang dan cinta, 3) Setiap anak tumbuh dalam rasa menghargai, 4) Setiap anak tumbuh dalam rasa aman.

Misi: 1) Mendirikan Keluarga-keluarga bagi anak yang kurang beruntung, 2) Membantu mereka membentuk masa depan sendiri, 3) Memberi kesemppatan kepada mereka berkembang dalam masyarakat. ${ }^{8}$

\section{METODE PENELITIAN}

Setiap kegiatan penelitian diperlukan suatu langkah pengkajian dengan menggunakan metode penelitian agar tujuan penelitian dapat tercapai seperti yang diharapkan. Metode penelitian sangat diperlukan untuk menemukan data yang valid dan pengembangan suatu pengetahuan serta dapat digunakan untuk menguji kebenaran suatu ilmu pengetahuan.

Adapun penelitian ini menggunakan pendekatan kualitatif dan jenis penelitian adalah deskriptif. Penelitian deskriptif adalah yang memperoleh data

\footnotetext{
${ }^{6}$ Ibid.

${ }^{7}$ Ibid.

${ }^{8}$ Ibid.
} 
berbentuk kata-kata atau gambar, sehingga tidak menekankan pada angka. ${ }^{9}$ Jenis penelitian kualitatif menggunakan beberapa bentuk pengumpulan data, seperti transkip wawancara terbuka, deskriptif, observasi, serta analisis dokumen dan artefak lainnya.

Teknik pengumpulan data yang digunakan dalam penelitian ini adalah dengan menggunakan data teoritis yaitu berupa studi kepustakaan dan data dari lapangan. Pengumpulan data dari lapangan dengan menggunakan wawancara dan dokumentasi. ${ }^{10}$

\section{LANDASAN TEORI}

\section{Pengertian komunikasi}

Secara etimologis istilah komunikasi berasal dari bahasa latin communication, perkataan ini bersumber pada kata communis yaitu sama, dalam arti sama makna, yaitu sama makna mengenai suatu hal. ${ }^{11}$ Sedangkan secara terminologi, para ahli mendefiniskan komunikasi adalah proses menyampaikan suatu pernyataan oleh seseorang kepada orang lain atau memberitahukan atau merubah sikap, pendapat dan perilaku baik secara langsung melalui lisan maupun tidak langsung dengan media. ${ }^{12}$

Menurut Kamus Bahasa Indonesia, komunikasi adalah pengiriman dan penerimaan pesan atau berita antara dua orang atau lebih sehingga pesan yang dimaksud dapat dipahami. ${ }^{13}$ Komunikasi adalah suatu proses dimana individu dalam hubungan dengan individu lainnya dalam kelompok, dalam organisasi dan dalam masyarakat guna memberkan suatu informasi. ${ }^{14}$

Berdasarkan pendapat di atas maka penulis menyimpulkan bahwa komunikasi adalah proses penyampaian pesan dari seseorang kepada orang lain baik secara langsung bertatap muka maupun secara tidak langsung melalui media

9 Sugiono, Metode Penelitian Pendidikan Pendekatan Kuantitatif, Kualitatif, dan R\&D (Bandung: Alfabeta CV, 2012), h. 22

${ }^{10}$ Ibid, h. 338

${ }^{11}$ Onong Uchjana Effendy, Dinamika Komunikasi (Bandung: PT. Remaja Rosdakarya, 1992), h. 4

12 Philip Astrid S, Komunikasi Dalam Teori dan Praktek (Bandung: Bina Cipta, 1998), h.1

${ }^{13}$ Departemen Pendidikan dan Kebudayaan, Kamus Bahasa Indonesia (Jakarta: Balai Pustaka,1995), Ed. 2

${ }^{14}$ Muhammad Arni, Komunikasi Organisasi (Jakarta: Bumi Aksara, 2001), Cet.4, h. 1 
dengan harapan adanya timbal balik setiap pesan yang disampaikan oleh pengirim (komunikator) kepada penerima (komunikan) dapat sama-sama memahami makna dan maksud dari pesan tersebut.

\section{Pola komunikasi}

Pola komunikasi menurut Djamarah, yaitu bentuk atau struktur hubungan dua orang atau lebih dalam proses pengirimana dan penerimaan pesan dengan cara yang tepat sehingga pesan yang dimaksud dapat dipahami. ${ }^{15}$ Menurut Joseph A. Devito membagi pola komunikasi menjadi empat, yakni komunikasi antarpribadi, komunikasi kelompok, komunikasi public dan komunikasi massa: ${ }^{16}$

1. Komunikasi Antarpribadi atau Antarpersonal, sanagt banyak pendapat tentang pola komunikasi ini salah satunya pendapat Trenholm \& Jonsen yaitu, komunikasi yang mengcu pada komunikator "diad" yaitu komunikasi antara dua individu, keduanya berbagi peran sebagai pengirim dan penerima, menjadikan keduanya terhubung melalui kegiatan yang saling menciptakan makna. Dapat disimpul bahwa komunikasi antarpribadi adalah komunikasi antara dua orang orang atau lebih secara tatap muka, pesan yang disampaikan berupa verbal atau nonverbal.

2. Komunikasi kelompok kecil yaitu komunikasi yang dilakukan beberapa orang yang bekerjasama untuk mencapaii tujuan bersama.

3. Komunikasi publik merupakan penyebaran informasi dari satu porang kepada orang banyak atau di depan umum.

4. Komunikasi massa yaitu komunikasi yang menggunakan media massa.

Menurut H. A.W Widjaja pada pola komunikasi ada 4 macam yaitu:

1. Pola Roda, pada pola roda ini seseorang (A) berkomunikasi pada banyak orang yaitu B, C, D dan E. Antara B, C, D dan E tidak saling berkomuikasi kecuali dengan A,

2. Pola Rantai, yaitu seseorang (A) berkomunikasi pada seseorang yang lain yaitu (B) dan seterusnya ke (C) ke (D) dan ke (E).

${ }^{15}$ loc.cit., h.1

${ }^{16}$ Ahmd Sultra Rustan \& Nurhakiki, Pengantar Ilmu Komunikasi ( Yogyakarta: CV Budi Utama, 2017), h. 64 
3. Pola lingkaran, yaitu sama dengan pola rantai, namun orang terakhir (E) berkomunikasi pula pada orang yang pertama (A).

4. Pola bintang, yaitu semua anggota berkomunikasi dengan sesama anggota. $^{17}$

\section{Bakat}

Bakat adalah konsisitensi karakteristik yang menunjukkan kapasitas seseorang untuk menguasai suatu pengetahuan khusus (dengan latihan), keterampilan atau serangkaian respon yang terorganisir. ${ }^{18}$ Menurut Fudyatanta, menyebutkan bahwa bakat akan dipengaruhi oleh faktor internal dan eksternal. Faktor Internal adalah faktor kematangan fisik atau kedewasaan biologis, peningkatan kualitas keterampilan fisik. Kematangan juga terjadi dalam segi mental psikologisnya, artinya bahwa semakin seseorang dapat mencapai kematangan fisik dan mental, maka bakatnya juga akan mengalami perkembangan. Selain itu lingkungan juga mempengaruhi perkembangan bakat seseorang. Lingkungan yang baik, pendidikan yang baik akan menunjang perkembanagan bakat-bakat yang ada pada individu-individu yang bersangkutan.

\section{Minat}

Minat adalah sebuah dorongan dari dalam diri seseorang atau faktor yang menimbulkan keterkaitan atau perhatian secara seleftif yang menyebabkan dipilihnya suatu objek atau kegiatan yang menguntungkan, menyenangkan dan lama-kelamaan akan mendatngkan kepuasan dalam dirinya. ${ }^{19}$

Desmita (2010) menjelaskan faktor-faktor yang mempengaruhi minat anak:

1. Faktor Internal

a. Faktor kesehatan, kesehatan jasmani dan rohani sangat besar pengaruh terhadap bakat minat anak. Bila seseorang kesehatannya terganggu semisal sakit pilek, demam, pusing, batuk dan sebagianya, dapat mengakibatkan cepat lelah, tidak bergairah dan tidak bersemangat melalkukan kativitas.

${ }^{17}$ H.A.W. Widjaja, Ilmu Komunikasi Pengantar Studi (Jakarta: PT. Rineka Cipta, 2000),

${ }^{18}$ Fudyartanta, Test Bakat dan Perskalaan Kecerdasan (Yogyakarta: Pustaka Belajar,2010)

${ }^{19}$ Hera Lestari Mikarsa, Pendidikan Anak SD (Jakarta: Universitas Terbuka, 2007), h.3 
b. Cacat tubuh yakni sesuatu yang menyebabkan kuran baik atau kurang sempurna mengenai tubuh. Cacat tubuh seperti buta, tuli, patah kaki, lumpuh dan sebaginya bisa mempengaruhi minat, anak yang cacat minat juga terganggu.

c. Faktor psikologis

a) Perhatian, untuk mencapai hasil minat yang baik, maka anak harus mempunyai perhatian terhadap bahan yang dipelajarinya, jika bahan atau materi tidak menjadi perhatian anak, maka minat yang timbul pun akan rendah.

b) Kesiapan, kesediaan untuk memberikan respon atau bereaksi. Kesediaan ini timbul dalam diri seseorang dan juga berhubungan dengan kematangan, karena kematangan berarti kesiapan untuk mencapai kecakapan.

2. Faktor keluarga, minat anak bisa dipengaruhi oleh kluarga sepert cara orangtua mendidik, seperti mendidik anak tidak baik jika terlalu dimanja dan juga tidak baik jika mendidik terlalu keras. Situasi rumah yang besar dan terlalu banyak penghuninya, suasana rumah yang tegang, ribut, sering cekcok akan menyebabkan anak bosan dirumah, dan sulit berkonsetrasi serta keadaan ekonomi keluarga. ${ }^{20}$

\section{PEMBAHASAN}

SOS children's Village berfokus pada pengasuhan berbasis keluarga dan berjangka panjang. Dasar tujuan dari pekerjaan di SOS adalah untuk menghormti, mempromosikan, dan membela hak-hak anak asuh. Fokus pekerjaan di SOS yaitu memberikan hak-hak anak yang sama untuk pendidikan dan pelatihan bagi anakanak yang keluarganya hidup dalam kondisi sulit, memperhatikan anak dan kesehatan anak dan memberi bantuan darurat bencana dengan cepat tanpa birokrasi dan dalam cara yang ditargetkan dalam situasi krisis, dalam situasi traumatis anakanak secara khusus membutuhkan perlindungan khuus dan perawatan intensif. SOS juga memperluas bidang kerja melalui Program pemberdayaan Keluarga untuk

\footnotetext{
${ }^{20}$ Desmita, Psikologi Perkembangan (Bandung: PT. Remaja Rosdakarya, 2010)
} 
keluarga yang kurang beruntung, untuk mencegah terjadinya kondisi terburuk yang bisa menyebabkan anak-anak harus terpisah dari orangtuanya.

Berdasarkan hasil penelitian yang dilakukan, dapat diuraikan pembahasan mengenai Pola Komunikasi Pengasuh dan Anak asuh dalam pengembangan bakat minat di SOS Desa Taruna Meulaboh Kabupaten Aceh barat.

\section{Pengembangan bakat minat anak di SOS children's Village Desa Taruna Meulaboh Kabupaten Aceh barat}

Orangtua menginginkan anaknya tumbuh dan berkembang secara optimal, khususnya ibu sangat berperan penting dalam pendidikan anak seperti mengembangkan bakat dan minat. Setiap anak tentunya mempunyai bakat dan minat masing-masing yang terkadang dia sendiri saja tidak mengetahui bakat yang ada dalam dirinya sehingga menjadikan bakat mereka itu terpendam. Tentunya peran pengasuh disini adalah melihat sejauh mana bakat dan minat yang dimiliki anak dan memberikan program yang sesuai dengan bakat dan minatnya sehingga dapat menunjang mereka ke arah tersebut. Misalnya bakat anak kepada bidang matematika maka perlu ada kegiatan seperti Les, kemudian bidang kesenian perlu diadakan kegiatan latihan seperti Vokal, tarian, dan lain-lain. Dengan adanya pengembangan bakat minat anak akan membuat mereka mampu terampil dalam bidang apapun sesuai bakat dan minat mereka.

Sebenarnya bakat diartikan sebagai kemampuan bawaan tanpa banyak campr tangan orang lain. Bakat biasanya beriringan dengan minat sehingga minat dapat diartikan sebagai keinginan yang mempuyai tujuan dan cita-cita dan berusaha mencapainya. Bakat dan minat anak perlu ada dukungan dari orangtua (pengasuh) sehingga dapat terasah secara optimal. Namun hal itu tidak berjalan sesuai prediksi. Anak yang sudah berbakat dalam satu bidang, tetapi orangtuanya (pengasuh) tidak mendukung bakat minat dari anak sehingga menjadi kontradiksi dengan sang anak. Maka pengasuh harus memberi pengertian kepada anak tentang sisi positif dan negatif dari bakat minatnya tersebut secara terbuka dan logis. Menurut informasi dari pengasuh, tidak semua anak bisa langsung memahami komunikasi seperti itu, mereka tidak ingin ada orang yang menghambat mereka, jika tetap diberi pengertian maka mereka akan menggerutu bahkan memberontak jika bakat minatnya tidak tersalurkan. 
Dengan begitu, maka pengasuh perlu memperluas cara pandang anak terhadap bakat minatnya, melihat sisi positif dan negatif dari bakat minat tersebut, jangan samapai anak hanya terpaku pada satu minat saja. Misalnya anak yang berminat pada bidang olahraga saja, selain dari pada olahraga maka dia tidak mau berpartisipasi ikut.Selain itu terkadang ada anak yang hanya mempunyai minat besar pada suatu bidang namun tidak punya bakat bahkan memerlukan biaya yang mahal.Oleh karena itu sebaiknya pengasuh memperkenalkan anak dengan teman sebaya lainnya yang memiliki beragam bakat minat, selain itu juga perlu motivasi dari pengasuh dengan menceritakan tentang orang-orang sukses yang berasal dari keluarga seperti mereka.Selain itu pengasuh juga perlu meluangkan waktu untuk hiburan anak-anak ketika weekend agar anak tidak bosan dan dan jenuh.

Adapun kegiatan yang dilakukan oleh SOS children's Village Desa Taruna Meulabohdalam Pengembangan bakat minat anak, yaitu :

1) Les Komputer setiap 2 kali dalam seminggu

2) Rapa'i Geleng (seni) setiap sekali dalam seminggu

3) Les Matematika, IPA, IPS

4) Kegiatan Tilawah

5) Vokal suara

Dari hasil interview dan observasi peneliti, bakat dan minat anak di SOS children's village semakin hari semakin bersemangat, dan seiringnya waktu anakanak sudah mulai tampil di luar daerah untuk mengikuti kegiatan-kegiatan sesuai bakat mereka, seperti sepak bola, volly, vokal, olimpiade Sains dan lain-lain.

\section{Pola komunikasi Pengasuh dan Anak asuh dalam pengembangan bakat minat di SOS children's Village Desa Taruna Meulaboh Kabupaten Aceh barat}

Pola komunikasi merupakan suatu hal yang sangat dibutuhkan bagi setiap anak dalam menjalankan aktivitas yang menunjang kepada pendidikan yang baik, seperti meningkatkan rasa percaya diri anak, melatih anak membiasakan diri dalam keadaan yang sulit, selalu berusaha mengembangkan bkat minatnya dan lain-lain, semua itu tentunya tidak terlepas dari pola komunikasi yang di lakukan.

Pola komunikasi adalah unsur yang menentukan berhasil atau tidaknya hubungan anak dan pengasuh dalam mengembangkan bakat minatnya. Di SOS 
children's Village Desa Taruna Meulaboh Kabupaten Aceh barat, para pengasuh harus mempunyai syarat-syarat sebagai komunikator, yaitu memiliki kredibilitas bagi komunikassinya, mempunyai wawasan yang luas, memiliki sikap yang baik, santun dalam komunikasi, dan memiliki daya tarik dalam artian mampu melalukan perubahan sikap kepada sang anak. Maka pengasuh di SOS children's Village Desa Taruna Meulaboh Kabupaten Aceh barat harus mempunyai riwayat pendidikan minimal Tingkat SMA.

Pada penelitian ini penulis menemukan beberapa pola komunikasi di SOS children's Village Desa Taruna Meulaboh Kabupaten Aceh barat, yaitu :

1. Pola Komunikasi Antar pribadi, yaitu pola yang dilakukan antara pengasuh dan anak asuh yang terjadi pada pengasuh menanyakan satu persatu anak asuh tentang kendala apa yang saat ini sedang mereka rasakan.

2. Pola komunikasi umum, yaitu ketika adanya kegiatan kunjungan oleh pemateri dari luar, yaitu TNI, Tenaga Medis, Guru, Dokter dan masih banyak lagi, maka disini pemateri sebagi komunikatornya dan anak-anak sebagai komunikannya saling timbal balik, setelah pemateri memberikan stimulus kepada anak maka akan ada respons berupa pertanyaanpertanyaan dari anak. Hal ini dapat memberikan motivasi dan membuka wawasan anak-anak terhadap persaingan diluar sehingga anak akan berusaha lebih giat lagi dalam mengasah kemampuan bakat dan minatnya.

3. Komunikasi kelompok adalah komunikasi yang dilakukan oleh 3 orang atau lebih yang mempunyai tujuan yang dikehendaki. Komunikasi ini terjadi pada saat kegiatan isti'mah atau memberikan motivasi kepada anak, dengan cara mengumpulkan semua pada jadwal yang telah ditentukan kemudian dibagikan kelompok, memberikan nasehat agar mereka tidak malas dalam mengembangkan bakat mereka demi tercapai cita-cita mereka.

Adapun menurut interview semua pola komunikasi yang diterapkan di SOS Childrens' Village terkadang-kadang adakalanya menurun, sama halnya seperti engasuhan dalam keluarga juga seperti itu, terkadang ada hambatan lain baik dari 
pengasuh maupun anak asuh. Seperti anak asuh yang punya karakter keras tidak bisa dinasehati secara baik, atau pengasuh yang merasa kewalahaan terhadap tingkah laku anaknya. Apapun solusinya jika anak asuh masih saja bersikeras terhadap keinginannya yang terkadang tidak baik untuknya, maka pengasuh akan terus menerus memberikan pencerahan kepada anak bahwa itu salah atau tidak baik dengan penyampaian yang lemah lembut serta memberikan sanksi bagi anak yang melakukan pelanggaran atau perbuatan yang kurang baik. Hukuman yang diberikan juga masih hal yang wajar seperti mencuci bak mandi, memutari lapangan SOS sebanyak 20 kali putaran, membersihkan aula tempat perkumpulan anak dan pengasuh dan masih banyak lagi.

Dengan hukuman-hukuman seperti di atas, menurut penulis itu adalah cara yang efektif karena anak-anak akan merasakan efek jera sehingga takut untuk mengulagi kesalahan yang lain. Perlu diingat bahwa pengasuh adalah orangtua pengganti bagi anak yang selalu menerma aspirasi dari anak, maka tugas pengasuh tetap berusaha memperbaiki sang anak, mengarahkan anak kepada bakat dan minat yang positif karena anak itu tergantung orangtuanya, jika baik pengasuhannya maka baik pula respon nya.

\section{KESIMPULAN}

Berdasarkan hasil penelitian dan pembahasan di atas maka dapat diperoleh kesimpulan tentang Pola Komunikasi Pengasuh Dan Anak Asuh Dalam Pengembangan Bakat Minat Di Sos Children's Village Desa Taruna Meulaboh Kabupaten Aceh Barat. Adapun kesimpulan yanag diperoleh adalah:

Bakat dan minat anak perlu ada dukungan dari orangtua (pengasuh) sehingga dapat terasah secara optimal. Pengasuh perlu memperluas cara pandang anak terhadap bakat minatnya, melihat sisi positif dan negatif dari bakat minat tersebut, jangan sampai anak hanya terpaku pada satu minat saja, selain itu juga perlu motivasi dari pengasuh dengan menceritakan tentang orang-orang sukses yang berasal dari keluarga seperti mereka kemudian pengasuh juga perlu meluangkan waktu untuk hiburan bagi anak asuh. Adapun kegiatan yang dilakukan oleh SOS children's Village Desa Taruna Meulabohdalam Pengembangan bakat minat anak, yaitu: Les Komputer setiap 2 kali dalam seminggu, Rapa'i Geleng 
(seni) setiap sekali dalam seminggu, Les Matematika, IPA, IPS, Kegiatan Tilawah dan Vokal suara.

Pola komunikasi adalah unsur yang menentukan berhasil atau tidaknya hubungan anak dan pengasuh dalam mengembangkan bakat minatnya. Adapun beberapa pola komunikasi yang diterapkan di SOS children's Village Desa Taruna Meulaboh Kabupaten Aceh barat, yaitu: Pola Komunikasi Antar pribadi, Pola komunikasi umum, dan Komunikasi kelompok. Dengan pola komunikasi yang sudah diterapkan maka akan membantu dan merangsang bakat dan minat anak asuh di SOS Children's Village Desa Taruna Meulaboh.

\section{DAFTAR PUSTAKA}

Djamarah, Syaiful Bahri. Pola Asuh Orang Tua dan Komunikasi Dalam Keluarga. Jakarta: PT. Rineka Cipta. 2017.

Devito, Joseph A. Komunikasi Antarmanusia. (Edisi ke-5), Pamulang-Tangerang Selatan: Karisma Publising Group. 2011.

Desmita. Psikologi Perkembangan. Bandung: PT. Remaja Rosdakarya. 2010.

Departemen Pendidikan dan Kebudayaan. Kamus Besar Bahasa Indonesia. (Edisi ke-2), Jakarta: Balai Pustaka. 1995.

Effendy, Onong Uchjana. Dinamika Komunikasi. Bandung: PT. Remaja Rosdakarya. 1992.

Fudyartanta, K. Test Bakat dan Perskalaan Kecerdasan. Yogyakarta: Pustaka Belajar. 2010.

Mikarsa, Hera Lestari. Pendidikan Anak SD. Jakarta: Universitas Terbuka. 2007.

Mulyana, Deddy. Ilmu Komunikasi Suatu Pengantar. Jakarta: PT. Remaja Rosdakarya. 2008.

Sugiono. Metode Penelitian Pendidikan Pendekatan Kuantitatif, Kualitataif, dan $R \& D$. Bandung: Alfabeta CV. 2012.

Susanto, Phil Astrid S. Komunikasi Dalam Teori dan Praktek. Bandung: Bina Cipta. 1998.

Arni, Muhammad. Komunikasi Organisasi. Jakarta: Bumi Aksara Cetakan Ke-4. 2001.

Widjaja, H.A.W. Ilmu Komunikasi Pengantar Studi. Yogyakarta: Rineka Cipta. 2000.

Sumber Referensi:

Tim Penyusun SOS, Profil SOS Desa Taruna Indonesia, Meulaboh: t.tp, t.th 